Sprachtypol. Univ. Forsch. (STUF), Berlin 56 (2003) 3, 234-251

Marc L. Greenberg (Lawrence)

\title{
Word prosody in Slovene from a typological perspective
}

\begin{abstract}
Slovene is, along with Serbo-Croatian, an example of a pitch-accent language, one of the only two remaining among the Slavic family. In most of the literature on Slovene, the data on the word-prosody features of this language are taken from the standardized system, a somewhat constructed entity based on the pitch-accent systems of selected dialects. The present survey attempts to give a coherent structural description of the word-prosodic phenomena as they are manifested in the extraordinarily variegated Slovene dialects; these in turn are compared to the standardized system as well as, where relevant, to typologically similar systems found in Croatian dialects. In addition, the key innovations that shaped the prosodic systems of Slovene dialects are discussed. Slovene emerges as a special set of types that share a tendency to concentrate prosodic distinctions - pitch and quantity - in the one stressed syllable of each accented word. Furthermore, these pitch and quantity distinctions in many dialects have become rephonologized as vowel-quality distinctions. A few aberrant local dialects have gained new pitch distinctions or unstressed quantity distinctions.
\end{abstract}

\section{Prozodija slovenske besede tipološko}

Slovenščina je kot srbohrvašcina tonemski jezik, eden izmed samo dveh, ki sta క̌e taka v slovanski jezikovni družini. Pretežni del strokovne literature o slovenščni jemlje podatke o besedni prozodiji tega jezika iz knjižnega sistema, ki je v določeni meri narejen na podlagi tonemskih sistemov izbranih nare $\checkmark$ tem pregledu skusam podati sovisen strukturni opis prozodičnih pojavov na besedni ravnini, kot obstajajo v izjemno pestrih slovenskih narečjih; slednja se primerjajo tudi s knjižnim sistemom in, kjer so razlogi, $s$ tipološko podobnimi sistemi $v$ hrvaških nareçjih. Dalje se obravnavajo ključne novosti, $k i$ so oblikovale prozodiěne sisteme slovenక̌̌ine. Pri tem se slovenščna pokaže kot poseben razred tipov, katerim je skupna težnja po umeక̌canju prozodičnih razločkov - tona in kvantitete - na edini naglašeni zlog vsake naglasnice. Taki tonski in kvantitetni razločki so se $\mathrm{v}$ številnih narečjih prefonologizirali kot razločki v kvaliteti samoglasnikov. Nekaj netipičnih manjših narexij je dobilo nove tonske ali kvantitetne razlocke $v$ nenaglašenih zlogih.

\section{Introduction}

With regard to word prosody, Slovene is frequently mentioned together with SerboCroatian ${ }^{1}$ as one of the two Slavic languages that display pitch-accent systems (BETHIN 1998: 112), as well as one of a small number of such languages in Europe, to the extent that it is mentioned at all (Fox 1999: 265-266). Like Serbo-Croatian, Slovene pitch co-occurs with stress placement (with one dialect-level exception, mentioned below), and pitch

1 Serbo-Croatian is used as a less cumbersome (albeit historically fraught cover term) to refer to the speech territory corresponding to the contemporary standard languages Croatian, Bosnian, Montenegrin, and Serbian. 
contrasts are limited to one syllable - the long, stressed syllable - of non-compound words (i.e., Slovene is not a contour-tone language). Unlike Serbo-Croatian, Slovene pitch contrasts are not restricted to the first syllable of the word, as in Standard Serbo-Croatian languages based on the Neo-Stokavian dialect. In this regard, Slovene is closer in type to the Kajkavian dialect (i.e., that spoken in and around Zagreb), ${ }^{2}$ the Cakavian dialect ${ }^{3}$ (Adriatic coast and inland along the southern border of Slovenia to the town of Karlovac), and, to a lesser extent, the Posavian Stokavian dialects spoken in Croatia, as well as in Croatian-speaking enclaves in Austria and Hungary. Further, Slovene shares with Kajkavian the proclivity for the association of prosodic features with vowel quality (i.e., only certain vowels may occur under a given set of prosodic conditions) as well as the elimination of quantity in unstressed syllables (partially preserved in Kajkavian). In part the typological similarities arise because Slovene, Kajkavian, Cakavian (as well as, to an extent, the Posavian Stokavian dialects in eastern Croatia) lie outside of the prosodically innovative areas of Stokavian; in part, as in the case of Slovene and Kajkavian, also because of shared or parallel innovation. Neither the Kajkavian nor the Cakavian dialect was accepted as a model for a standard language, and thus information about them appears in more specialized works; hence they are usually excluded from surveys of SerboCroatian prosody written for a non-Slavist audience.

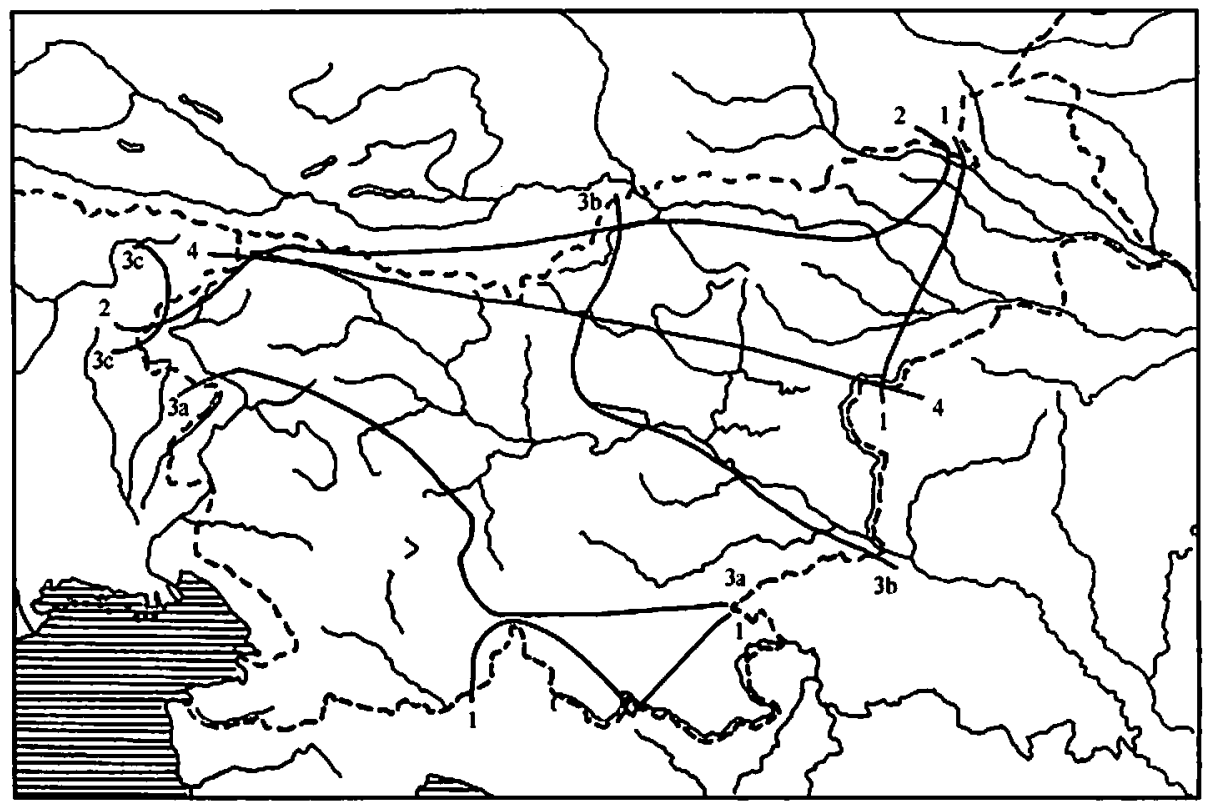

Map 1

Dashed lines $=$ state borders

North and west of isogloss $1=$ lengthening of non-final short stress

North of isogloss 2 = late lengthening of non-final short stress (with new vowel qualities)

North of isogloss $3 a$, south of isogloss $3 b$, east of isogloss $3 c=$ retention of pitch distinctions

North of isogloss 4 = retraction of non-initial "circumflex" tone (za'bà:va > 'zá:bava 'amusement')

2 The Kajkavian area begins east of the border defined by areas III and IV in Map 2.

3 The Cakavian-speaking territory reaches to the Slovene border south of area II in Map 2. 
Although Slovene speakers number only about 2 million, the dialects vary considerably, as do the prosodic configurations found in the Slovene speech territory. Pitch accent is limited to a swath of the territory from the northwest to the southeast (in Map 1, showing the major prosodic isoglosses in Slovene speech territory, the area circumscribed by isoglosses $3 a-c$ ), running through the center. Roughly in the middle of this territory is the capital, Ljubljana (see Map 2, depicting Slovene dialects), on the urban dialect of which the pitch-accent variant of the idealized standard system is based. Elsewhere, pitch accent has been lost and replaced by systems that distinguish quantity in the stressed syllable or where quantity systems have developed into stress-only systems. Typically, Slovene dialects have rephonologized quantity distinctions as vowel-quality distinctions, a leitmotif that runs through the history of Slovene, and many dialects, particularly around the periphery, have lost pitch contrasts (for details see GREENBERG 1987, 1992, 2000).

\section{Pitch configurations in Standard Slovene and Slovene dialects}

Standard Slovene recognizes two varieties of accentuation, one corresponding in type to a pitch-accent system found in the central dialects of Upper and Lower Carniola (areas I and II, respectively, on Map 2; the capital, Ljubljana, straddles the border between these two dialects); the other corresponding to this system minus pitch distinctions. In this way the standard language provides two target systems for speakers from disparate dialect areas, the former for those whose native speech includes tonal contrasts, the latter for those whose speech does not (Toporišic 2000: 63).

A long history of acoustic investigation on the phonological features of Slovene tonemes has resulted in a reasonably coherent understanding of the properties of word-prosody in the standard pronunciation (see especially Toposišıc 1967, 1968 [and works cited in these two articles for references to earlier analyses]; SREBOT-REJEC 1988, 1997, 1999), as well as in selected Carinthian dialects spoken in Austria (area V in Map 2; see NeweKLowsKy 1973). With respect to Standard Slovene, the distinction between the "acute" and "circumflex" accents - to use the traditional terms - amounts to a contrast in pitch movement in the tonic syllable (acute $=\mathrm{LH}$, circumflex $=\mathrm{HL}$ ), supported by a syntagmatic contrast between pitch in the tonic (stressed) syllable versus the first post-tonic syllable when the second of these two syllables is available and not otherwise neutralized by sentence intonation. Thus, in words that contain a post-tonic (unstressed) syllable, the phonologically relevant feature is the relative difference in pitch between the stressed syllable and the following one: the acute is realized by relatively lower pitch in the accented syllable followed by higher pitch in the post-tonic syllable; the circumflex is realized by relatively higher pitch in the accented syllable followed by lower pitch in the post-tonic syllable (though the pitch contrast is much narrower with the circumflex than the acute). When the post-tonic syllable is absent or neutralized, the contrast is signaled only by the pitch movement within the stressed syllable. The acute is realized by falling-rising pitch contour (often described as "concave" in the phonetic literature); the circumflex is realized by rising-falling pitch contour ("convex"). In absolute terms, as measured by machine, acute-stressed syllables have lower pitch than circumflex-stressed (Toporišıc 1968: 322-323, 392-393; SREBOt-REJEC 1988: 229-230). Short stress, which is limited to the word-final syllable, generally carries the pitch characteristics associated with the circumflex, but this is not contrasted by a 
corresponding acute. Examples ("acute"): 'láis 'hair (GEN. PL)', 'krásvo 'cow (ACC. SG)'; (“circumflex”): 'là:s 'hair (NOM. SG)', 'krà'v' 'cow (INSTR. SG)', 'jà:s 'clearings, for example, in a forest (GEN. PL)'; (short-stressed): 'brat 'brother'. In the non-tonemic variety of the standard language, the contrast in pitch is eliminated: 'lais 'hair (NOM. SG)' or 'hair (GEN. PL)', 'kra:vo 'cow (ACC. SG)' or 'cow (INSTR. SG)'; and the quantity contrast in final or monosyllabic words is maintained: 'brat 'brother', 'jaz ' $\mathrm{I}$. ${ }^{5}$ The relationships are schematized in Table 1, showing stress and pitch associations in Standard Slovene; here the phonetic complexity is ignored in favor of the relative pitch relationships that are relevant in the perception of Standard Slovene tones. ${ }^{6}$

The pitch relationships in pitch-distinguishing dialects may differ in significant ways in their realization. For example, in the Podjuna/Jauntal dialect (Map 2: area 22), as NewEKL.OWSKY has demonstrated, pitch distinctions are signaled solely by the contrast in the stressed syllable, the post-tonic syllable being as a rule lower in pitch than either the acute- or circumflex-stressed syllable (1973: $97 \mathrm{ff} ., 138)$. In the western part of the Rož/Rosental dialect (Map 2: area 24), both the tonic and post-tonic syllables are required for the identification of the pitch contrast, so that pitch is neutralized in long monosyllabic words (1973: 139). The Rož/Rosental system has often been considered somewhat unusual, as the pitch peak is reached in the second, post-tonic, syllable of bisyllabic words (1973: 141 and earlier literature cited there). The eastern part of Roz/Rosental matches the system found in Podjuna/Jauntal just described (1973: 139).

4 Examples are given in broad phonetic transcription.

5 According to Srebot-Rejec (1988) and Petek, Šustaaš̀ı \& Komar (1996) the distinction between long and short syllables is not observed by the speakers that they investigated. In both studies, the code in question was "Standard Slovene", which implies that the speakers aimed for an idealized system. The problem with this is that the "standard" system, with regard to vowel quantity, did not exist in reality in the first place. To illustrate, in the central dialects of Slovene that were used as the primary models for the standard language, short stressed high vowels in final closed syllables became centralized, and short unstressed high vowels in word-final position were eliminated. Thus, historically, "kup 'pile' had become 'kəp and *'kü:pi 's/he buys' had become 'kui:p (a modern-day construct, post-verbal 'kù:p 'purchase', is cited by Petek, Šustaršı \& Komar). In the creation of the national standard language in the nineteenth century, dialectal $k \curvearrowright p$ was replaced by language planners with the reconstructed form $k u p$ at a time well after all examples of short $/ \mathrm{u} / \mathrm{had}$ already been eliminated from the organic spoken system. Though the language planners may have intended spenkers to acquire a new length distinction, it is doubtful whether it was in fact learned by non-specialists. Today one must account for a variety of types of speakers with varying relationships to standard pronunciation. For example, dialect speakers of Upper Carniolan (Map 2: area 1) that code switch between their dialect and Standard Slovene know dialectal 'kłp, küip corresponding to (standard) $k u p$, and kup(i); speakers from Prekmurje (Map 2: area 16) know 'kyp, ky:pr alongside the standard forms, whereas Ljubljana speakers raised in educated, standard-only, families, know only the standard forms (however they may pronounce them). The former two dialect/standard speakers stand a good chance of translating the vowel quality-and/or quantity-relationships that hold in their dialect speech into the standard, while the standard-only speaker has little chance of doing so. For further discussion, see section 7 below.

- From this point on, the terms acute and circumflex will be used as shorthand referring to rising and falling tones, respectively. This follows the practice in Slovene dialectological literature. 


\begin{tabular}{|c|c|c|}
\hline & abic & Monosyllabic \\
\hline \multicolumn{3}{|c|}{ Acute } \\
\hline $\mathrm{L}[\mathrm{H}]$ & $\mathbf{H}$ & LH \\
\hline kra: & vo & la:s \\
\hline * & & * \\
\hline 'cow & (ACC.sG)' & 'hair (NOM.sG)' \\
\hline \multicolumn{3}{|c|}{ Circumflex } \\
\hline $\mathrm{H}[\mathrm{L}]$ & L & HL \\
\hline kra: & vo & la:s \\
\hline$*$ & & * \\
\hline cow & (INSTR.SG)' & 'hair (GEN.PL)' \\
\hline
\end{tabular}

Table 1

\section{Lexical assignment of accent}

The surface accentual properties of words can be determined by an algorithm applied in the concatenation of individual morphemes, each of which is marked or unmarked for an underlying prosodic feature. For example, the underlying pitch of each morpheme may be specified as either rising, falling, or unmarked: <ríb-á 'fish-NoM.SG.FEM', <ríb-o> 'fishACC.SG.FEM', <ríb-6:> 'fish-INSTR.SG.FEM'; <glà:v-á> 'head-NOM.SG.FEM', <glà:v-o> 'headACC.SG.FEM',<glà:v- 6 :> 'head-INSTR.SG.FEM' To the underlying forms is applied an ordered set of rules. Here the relevant rules to generate the correct forms would be as follows: (1) Place of stress is assigned to the first rising-pitch morpheme, pitch in the remaining morphemes of these word-forms is ignored; (2) Any remaining falling pitch is shifted one syllable to the right, any length in the ceding syllable is shortened, and the newly stressed syllable becomes long; (3) If a rising-pitch syllable is followed by a long vowel, that long vowel is shortened and the rising pitch becomes falling; (4) Short final stress is retracted one syllable, yielding rising pitch on that syllable. The resultant forms are (Standard Slovene ${ }^{7}$ ) 'rí:ba, 'ríbo, 'rìbo; 'glá:va, 'glavòi, gla'vó:. This illustration is only a fragment of the elements required for an adequate account of the inflectional and derivational distribution of accentual types. The elaboration of this algorithm is beyond the scope of this paper, but the interested reader may refer to Toporišı 1988 , who gives rules that hew close to the diachronic changes that gave rise to the surface forms; GvozDaNovic 1999 presents a partial, but more streamlined, strictly synchronic account.

7 Strictly speaking, these examples are the historically correct forms that were considered the prevailing standard until about World War II, some of which are now considered archaic and/or dialectal. In particular, the end-stressed forms of the glava paradigm have been analogized to the stem-stressed pattern, like riba. 

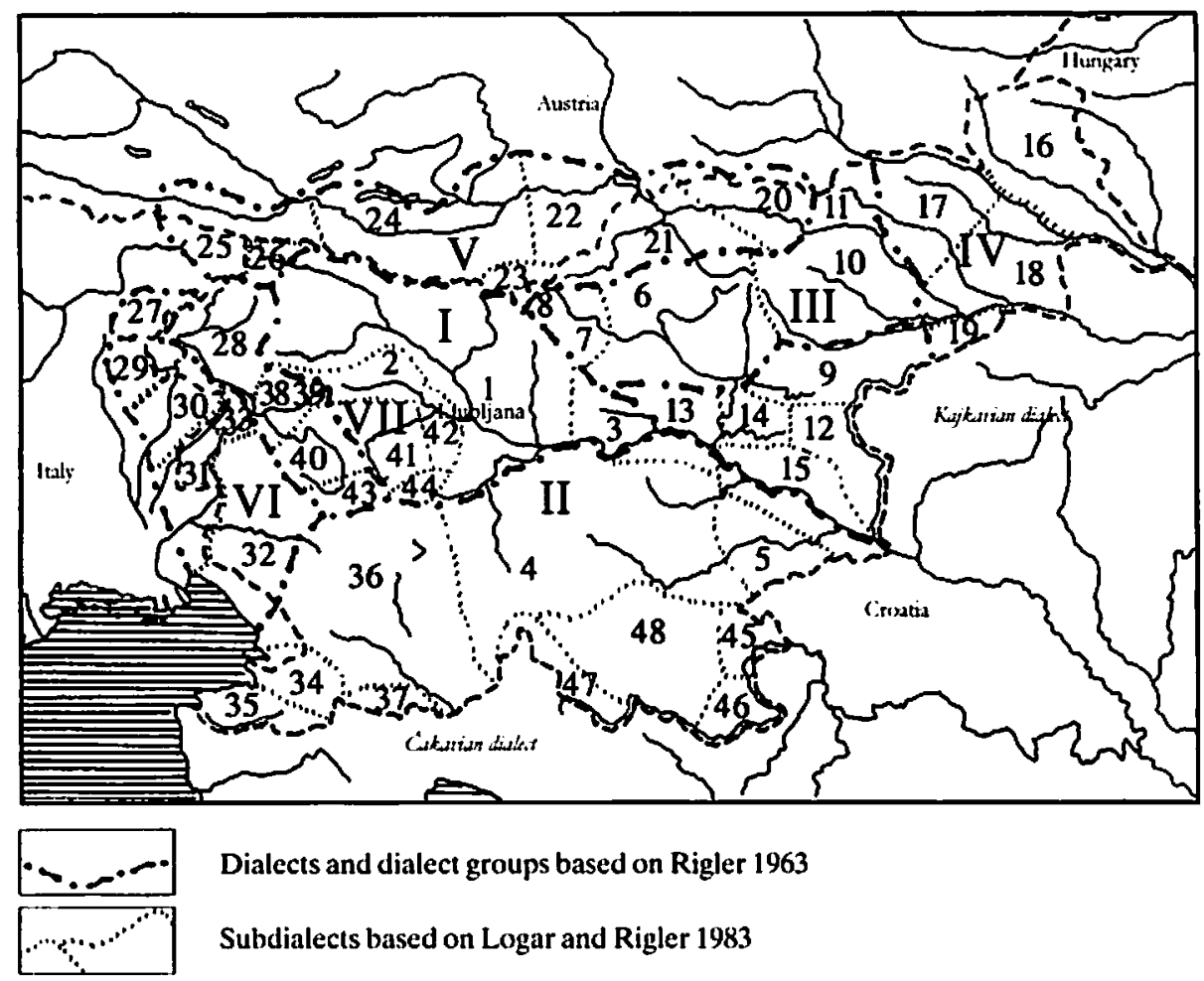

Dialects and dialect groups based on Rigler 1963

Subdialects based on Logar and Rigler 1983

$-2-1,-\sqrt{-1}$

National borders

Map 2

I. Upper Carniolan dialect, II. Lower Carniolan dialect. III. Styrian dialect. IV. Pannonian dialect group, V. Carinthian dialect, VI. Littoral group, VII. Rovte group; 45-48. dialects of heterogeneous origin. Arabic numerals denote individual subdialects. Those relevant to the discussion are identified by name in the text.

\section{Elimination of vowel quantity, stress advancement and retraction}

Vowel quantity in unstressed syllables has been gradually removed in Slovene dialects through a number of processes. At the beginning of the emergence of Slovene as a distinct dialect of Common Slavic, circa AD 1000 , part of the quantity distinctions in both stressed and unstressed syllables was removed by a complex set of changes involving the inherited (Common Slavic) falling pitch in the first syllable. The change has been noted also in parts of the Croatian Kajkavian dialect, particularly in areas bordering with Slovenia (see Ivic 1982: 186). As has been demonstrated in GREENBERG 1992, this change resulted in the shift of stress one syllable to the right, first in heavy syllables containing a long vowel and later, in a hierarchical fashion, to syllables that were light and contained a short vowel. Towards the periphery of the dialect territory, not all instances of the shift were carried out. Predictably, these instances are in the structures that were less favorable to shift. The advancement hierarchy development is illustrated in Table 2. Part of this change involves the loss of quantity distinctions in the ceding syllable, which became (or remained) redundantly 


\begin{tabular}{|c|c|c|c|c|c|c|c|c|}
\hline $\begin{array}{l}\text { Syllable } \\
\text { structure }\end{array}$ & $\begin{array}{l}\text { Common } \\
\text { Slavic }\end{array}$ & Standard Slovene & 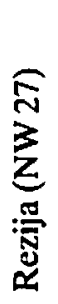 & 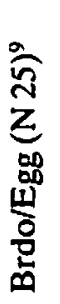 & 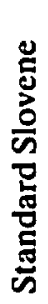 & 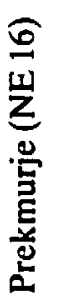 & 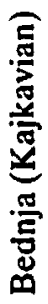 & 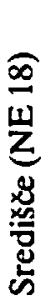 \\
\hline 'càcv & 'sàto & s'tò: 'hundred' & + & + & + & + & + & + \\
\hline 'cv̀:cvic & 'bù:diat" & bu'diat 'to awaken' & - & \pm & + & + & + & + \\
\hline 'cr̀cv:c & 'gòlo:b' & go'lò:b 'pigeon' & - & \pm & + & + & + & + \\
\hline 'cùcuc & 'vèt fer' & vefè̀rr 'evening' & - & \pm & + & + & + & + \\
\hline 'cr̀̀cv: & 'nògo: & no'gò:10 'foot (ACC.SG)' & - & \pm & + & + & \pm & - \\
\hline 'cv̀:cvi & 'rò:ko: & ro'ko: 'hand (ACC.sG)' & - & \pm & + & + & - & - \\
\hline 'cv̀:cv & 'mè̀:so & $m \varepsilon$ 'sò: 'meat' & - & \pm & + & + & - & - \\
\hline 'cv̀cv & 'óko & o'kò: 'eye' & - & \pm & + & + & - & - \\
\hline 'cive ${ }^{3} \mathrm{cr}$ & 'pòb ra:lo & psb'rà:w 'took' & - & \pm & + & - & - & - \\
\hline
\end{tabular}

Table 2

Note: The geographical abbreviations and numbers following the dialects refer to Map 2.

short. The second, newly stressed, syllable, contained a falling pitch and became redundantly long. In the case of monosyllabic words, i.e., those that lost a weak schwa (jer) or had the structure CV, the stressed vowel became (or remained) long, e.g., *'dòm > St. SI. 'do:m 'home', *'kàdo > g'dó: ' 'who', " 'tò > 'tò: 'this (NEUT.SG)'.

Stressed vowel quantity has been eliminated in most Slovene dialects by an innovation dating to approximately the $14^{\text {th }}$ century that resulted in the lengthening of all non-wordfinal short stresses (see isogloss 1, Map 1), e.g., "po'tóka > po'tó:ka 'stream (GEN.SG)', *bo'gáta > bo'gá:ta 'wealthy (FEM.SG)'. This lengthening resulted in a long rising stress that merged with long rising stress from other sources. After this innovation, quantity contrasts persisted only in word-final position, e.g., pos' tà: $w$ 'figures, laws (GEN.PL)', pos'tàw 'became (MASC.SG)'.

8 The form has become rising-stressed, apparently under the influence of interrogative sentence intonation. Instances of the original falling word prosody can be found in dialects.

9 In the Brdo/Egg dialect, the shift has taken place only partially in that the ictus has remained in place on the first syllable, but the pitch peak has moved to the second, resulting in rising pitch in the first syllable. The resulting rising-stressed syllable is long, unless closed, where it is (redundantly) shortened according to the phonetic rules peculiar to this village dialect (for details see Grafenauer 1905).

10 In modern Standard Slovene the accentuation of the accusative singular of noga 'foot' and roka 'hand' bas been replaced by rising stress in the first syllable, a development that is specific to bisyllabic feminine nouns that end in $-a$ in the NOM.sG. 
A second complex set of changes eliminating unstressed vowel quantity is the removal of final short-stressed syllables one syllable to the left. Like the changes described in section 4 , paragraph 1 , this set of changes occurred in a stepwise fashion, with retraction beginning in words with long pre-tonic vowels, then short pre-tonics, then in pre-tonics containing a schwa, with closed final syllables lagging behind open final syllables. The progress of the retractions is summarized in the hierarchy in Table 3. The first three types have taken place in all Slovene dialects and are thus the oldest, having taken place by the $11^{\text {th }}$ century. Later types have continued to develop until the present day. The final two types involve the retraction of the final long falling stress that had developed from advancement of the inherited initial falling tone. This retraction is characteristic of the southern periphery (here represented by the village dialect of Babno Polje, in area 47 on Map 2), where contact with historically discontinuous Croatian dialects lacking the advancement innovation may have contributed to the celerity of the innovations. Elsewhere in Slovene, the retractions have spread in a typical center-periphery fashion, with the center of the innovations being in the north-central region. In those dialects that had undergone the lengthening of non-final short stress described above in section 4, paragraph 2, the retraction onto short pre-tonic syllables resulted in a long syllable, but (in many dialects and the standard language) with a new quality contrast, for example, "'vól'a > 'vó:lja 'will', *ko'sa > 'kś:sa 'scythe'. Further

\begin{tabular}{|c|c|c|c|c|c|c|c|c|}
\hline $\begin{array}{l}\text { Syllable } \\
\text { structure }\end{array}$ & $\begin{array}{l}\text { Common } \\
\text { Slavid } \\
\text { Common } \\
\text { Slovene }\end{array}$ & Standard Slovene & 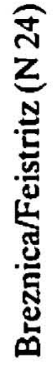 & 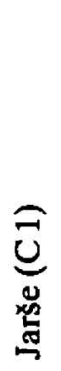 & 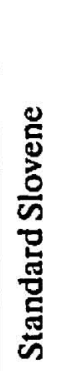 & 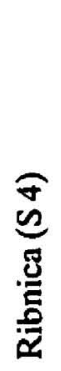 & 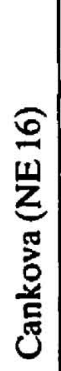 & 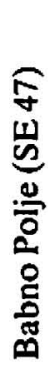 \\
\hline$c v:^{\prime} c^{2}$ & gla:'w' & g'lá:w 'heads (GEN.PL)' & + & + & + & + & + & + \\
\hline$c v^{\prime} c^{\circ}$ & $m o^{\prime} j^{2}$ & 'mó:j 'my (MASc.sG)' & + & + & + & + & + & + \\
\hline cv:'cv & $d u: \int^{\prime} a$ & 'dú:fa 'soul' & + & + & + & + & + & + \\
\hline cv:'cve & $k u:^{\prime} p \partial c^{2}$ & 'ku:pac 'buyer' & - & + & + & + & + & + \\
\hline $\mathrm{cv} c \mathrm{cv}$ & $z e m^{\prime} l^{j} a$ & 'zé:mlja 'land' & - & + & + & + & + & + \\
\hline cv'cve & ot'rok & t'rok 'child' & - & - & - & \pm & + & + \\
\hline ca'cr & magla & $m ə g$ 'la, 'mágla 'fog' & - & - & \pm & - & + & + \\
\hline ca'cre & to'man' & to'man, 'támən 'dark' & - & - & \pm & - & + & + \\
\hline cv'cv: & 'mè̀:so & $m \varepsilon ' s o:$ 'meat' & - & - & - & - & - & + \\
\hline cv'cv:c & 'gòlo:b' & go'lò:b 'pigeon' & - & - & - & - & - & + \\
\hline
\end{tabular}

Table 3

Note: The geographical abbreviations and numbers following the dialects refer to Map 2. 
detail on the retraction hierarchies can be found in GREENBERG 2000: 93-94, 120-121, 143-44, 162-63, 183-185.

In the Croatian Kajkavian dialect, a retraction hierarchy similar to that found in Slovene can also be found. A seemingly significant difference, however, is in the appearance of two innovative types. One is the appearance of bisyllabic words with short final stress and a lengthened pre-tonic vowel, e.g., " $v o$ 'da > vo:'da 'water'; this is presumably the precursor to the retracted type 'vo:da. The former type is found along the Slovene border area north of the Sava and south of the Drava River; the latter is widespread throughout the Kajkavian dialect area. According to Ivić, the areal of lengthening in the first syllable stretches from the Julian Alps to Turopolje, south of Zagreb (for details see Ivić 1982: 184). The question remains whether in Slovene pre-tonic lengthening ever preceded retraction, because all attested instances of length in the type 'vo:da in Slovene are manifested in those words that have already undergone retraction (NB: this is the same as the example 'zé:mlja in Table 3).

\section{Loss of pitch}

Little detailed work has been done on the causes of tone loss in Slovene dialects." Nevertheless, some generalizations can be made that may be revised and refined upon closer examination of the facts. First, it is clear that pitch distinctions have a low functional load; i.e., there are relatively few words that are distinguished solely by pitch. Rather, pitch functions primarily in sharpening or clarifying the morphophonemic shape of words. It might be assumed that pitch contrasts could be safely ignored by successive generations of speakers without danger of losing semantic efficiency. Secondly, pitch contrasts in many dialects have given way to quantity and/or vowel-quality distinctions. In instances where pitch contrasts co-varied either with quantity or quality contrasts, speakers were free to interpret pitch, quantity, or quality as the basic, underlying distinctive feature. Thirdly. although there are many issues yet to be sorted out, language contact has played a substantial role in the loss of suprasegmental features.

As can be seen in Map 1, the largest geographical loss of pitch-accent occurs in two large areas, as defined by isoglosses $3 a$ and $3 b$. The territory south and west of isogloss $3 a$ is non-pitch-distinguishing, just as the area north and east of $3 \mathrm{~b}$. Somewhat contrary to expectations, this leaves the "center" of the linguistic territory the archaic one with respect to the retention of pitch. However, in this case the loss of pitch as an areal phenomenon emanates from two disparate areas, one the southwestern periphery of the speech territory, the other northeastern periphery. The isoglosses, as one might expect, are dynamic, as the center - the Upper and Lower Carniolan dialects (areas I and II in Map 2), as well as parts of Rovte (area VII) - have begun losing ground to non-pitch-distinguishing areas, that is, the Eastern Upper Carniolan dialect (3), the Eastern Lower Carniolan dialect (5), the Inner-Carniolan dialect (34-37) and the heterogeneous dialects in the southeast (45-48).

Tone loss may have occurred gradually, as a conditioned change, at least in some dialects; in others, dialect mixture and language contact apparently caused loss of pitch distinctions. A number of developments have been noted.

1 To my knowledge, the topic is treated as the focus of a sludy only in LUNDBERG $2001 \mathrm{a}$ and $2001 \mathrm{~b}$. 
Rigler reports for much of the Lower Carniolan dialect (Map 2, area II) the neutralization of acute and circumflex accent in the final syllable in favor of a (phonetically) falling tone. The central and western territory of this dialect, indicated as area 4 on Map 2, is largely conservative with respect to the retention of acute and circumflex in all positions. In the western corner of area 4 , the acute is not found in final long syllables. The eastern part of area 4 displays the neutralization of acute and circumflex in final long syllables (RIGLer 1980). Rigler points out that in Grosuplje, a small town in the center of area 4, pitch is neutralized only in certain grammatical endings, apparently by analogy. However, he implies that the neutralization is also phonetically conditioned, pointing out that the "further east one goes [from Grosuplje], the less one hears a clear final acute" (221). If both morphological and phonetic factors are at work, the phonetic innovation seems to be closing in from the periphery towards the center, i.e., from both the west and east, as indicated by the geographical distribution of pitch loss. In area 5, which represents the eastern third of the Lower Carniolan dialect, pitch distinctions have been lost altogether. In contiguous areas, 36 to the west, 13, 14, 15, pitch distinctions have also been lost. From here to the north and east, in Slovene-speaking areas bordering with German, Hungarian, and Croatian speech territories, there are no pitch-distinguishing Slovene dialects. Area 36, Inner Carniolan, while genetically closely related to the Lower Carniolan dialect, shares with neighboring Slovene dialects to the west the influence of Italian sentence and word prosody, which appear to have played the predominant role in the loss of pitch in these areas.

Parallel to the development in Lower Carniolan, some Upper Carniolan (Map 2: area 3) and Carinthian (areas 20 and 21) dialects have also lost pitch distinctions; these areas are in the eastern frontiers of the dialects, contiguous to non-pitch-distinguishing dialects to the east, the Styrian (area III) and Pannonian (area IV) dialect groups. Dialects 3 (eastern Upper Carniola), 20 (Northern Pohorje-Remšnik), and 21 (Mežica) display a number of characteristics that indicate dialect mixture with their eastern neighbors.

In contrast with the typical development in Styrian and Pannonian groups, the Haloze dialect (area 19), which is traditionally grouped as part of the Pannonian group, displays a curiously divergent configuration. With the exception of the Haloze dialect, Pannonian dialects typically display a (redundant) high pitch in the stressed syllable, followed by a lower pitch in the post-tonic syllable. Eastern Haloze, on the other hand, displays a rising tone in the stressed syllable, slightly declining towards at the end of this syllable and then continuing into the post-tonic syllable. LUNDBERG, who has performed the only acoustical analysis of this dialect to date, identifies this rising pattern as identical to that of the rising pitch contour in neighboring Kajkavian (i.e., Croatian) dialects to the east, where pitch contrasts in stressed syllables are found. According to LUNDBERG, this is one of the features indicating the heterogeneity of the Haloze dialect; i.e., it is genetically partly Kajkavian (2001 a: 182-184; 2001 b).

\section{Re-emergence of pitch}

Some localities on the western periphery of Slovene (areas 29, 30, 31 on Map 2) have gained a new rising tone after the loss of contrastive pitch. This development must be recent, as it arose after the retraction of short final stress onto etymologically short vowels, which resulted in a non-contrastive long falling tone, e.g., Šmartno v Brdih *sest'ra > 
'sè: stra 'sister', "ko'sa > 'kò:sa 'scythe', *məg'la > 'mo:hla 'fog'. After this development, word-final high vowels were eliminated (see section 7 , paragraph 7 , below), which resulted in a rising tone if the (heretofore) penultimate syllable was stressed. The resulting risingpitch syllable is further differentiated from (now) contrasting falling-pitch syllable by additional length (LOGAR 1981 a: 58).

At first glance it would seem appropriate - or, at least, tempting - to explain this development as a result of the reanalysis of vowel height as higher pitch, which was, after the loss of the final segment, copied into the new final syllable. Such a development, while intuitively natural, is infrequent in languages, at least insofar as the correlation of vowel height with pitch perception is concerned (Homberr 1978: 96ff.). As it turns out, the Smartno development probably results from the movement of a (heretofore) redundant final high tone to the preceding syllable concomitant with the loss of the final segment. This interpretation is more likely in light of the fact that internal loss of high vowels in syllables immediately following stress have not resulted in the emergence of rising pitch, e.g., " $t$ 'rd: vica > t'rà : $f c a$ 'grass'. Furthermore, this notion is supported by the parallel in some Carinthian dialects, e.g., Potoče/Potschach (area V, Map 2, in particular area 25), where non-contrastive unstressed high pitch in final syllables of all accented words is reported by LoGAR (1981 b: 184).

\section{Relationship of quantity to quality distinctions}

Historically, Slovene word prosody has moved from a system in which quantity played a significant role to one in which the role of quantity has been minimized or eliminated altogether. Broadly speaking, the changes that led towards the system described in section 2 involve the elimination of quantity oppositions, first in unstressed and then in stressed syllables, and the rephonologization of quantitative oppositions as vowel-quality oppositions.

The earliest changes in quantity, which have an areal greater than the modern Slovene speech territory, but limited to a portion of South Slavic - i.e., Slovene and Kajkavian did not effect any qualitative changes. Thus, for example, the loss of post-tonic quantity, common to the areas just mentioned, left the unstressed quality relations intact, i.e., unstressed vowels remained identical to their etymological equivalents whether they were previously long or short. The loss of post-tonic quantity can be dated to a time roughly up to the $11^{\text {th }}$ century AD (GREENBERG 2000: 110).

One of the earliest prosodic changes $\left(10^{\text {th }}-11^{\text {th }} \mathrm{cc}\right.$.) associated with Slovene in the narrow sense is the shift of all falling stressed syllables to the adjacent syllable to the right. In this process, the originally stressed syllable shortened, if long, or remained short otherwise, and the newly stressed syllable was realized as long, regardless of its inherited quantity. If no viable (i.e., containing a vowel other than schwa) second syllable was available, no shift occurred, but the resulting stressed syllable became (or remained) long and falling (for details, see GreEnBerg 2000: 105-109 and section 5 of this paper), e.g., *'òko > St. Sl. o'kò: 'eye', *'mè:so > me'sò: 'meat', *'bòg > 'bò:g 'God'.

Following the advancement and generalization of length to the falling-stressed syllables, the low-mid long vowel *a: raised to become the front high-mid correlate of * $o:$ These two vowels subsequently developed in tandem, becoming diphthongs $i e$, Slovene, ei, ou in southeastern Slovene, and remaining monophthongal in Upper Carniolan (Map 2, area I). In many dialects, save for those in the center that underwent subsequent 
mergers of long and short-stressed vowels, these long reflexes de-coupled from their short partners.

The late lengthening of non-final short rising stressed syllables resulted in an exceptionally complex stressed vowel system in the village dialect of Kneža/Grafenbach in Carinthia (Map 2, area 22). Table 4 illustrates the long stressed vowels in this system, where the boxes indicate the relatively recent additions due to rephonologization of quantity (from LOGAR 1981 c).

i:

iə

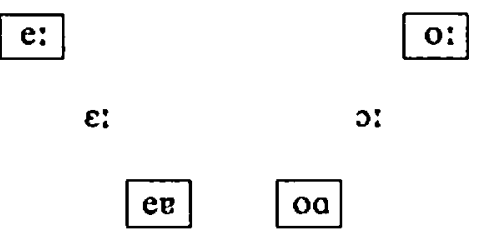

a: u:

$\mathbf{u}$

Table 4

A more recent example of rephonologization of quantity relationships can be seen in the comparison of two village dialects from the Prekmurje dialect (Map 2, area 16). Prekmurje lies outside of the innovation in which non-final short rising stress was lengthened, which eliminated quantity contrasts in non-final stressed syllables (see Map 1, isogloss 1).12 For example, in the village of Cankova in southwestern Prekmurje, the forms 'brot, 'broto 'brother (NOM.SG, ACC/GEN.SG)' correspond to Standard Slovene 'brat, 'brá:ta. Under conditions in which stressed length was preserved, the reflex of * $a$ differs both in quantity and quality, e.g., 'gla:vs 'head (NOM. SG)', Standard Slovene 'gláva. For this reason most instances of quantity contrasts in the Cankova system are redundant (though some vowels, $/ \mathrm{i} /, \mathrm{u} /, / \mathrm{y} /$, and $/ \mathrm{e} /$, maintain purely quantitative contrasts under stress). The village dialect of Martinje, some 15 kilometers to the north, has taken this system a step further and eliminated all stressed quantity contrasts and diphthongized most short stressed vowels, cf. 'broat, 'broats, but 'gla:v. Interestingly, the high long stressed vowels that in the Cankova system retained quantity distinctions have the reverse pattern in Martinje: long stressed high vowels have been converted to stressed diphthongs ('soin 'son' 'syu' $\int_{\Lambda}$ 'drought', cf. Cankova 'si:n, 'sy: fo) and historically short stressed vowels have remained monophthongs (si'fi:ti 'to dry', 'Sy:ji 'hears ( $3^{\text {rd }} \mathrm{sG}$ )', cf. Cankova sı'fitı, 'Syje).

An ongoing process in Slovene dialects, as well as the spoken realization of the standard language, is the reduction of high vowels. The process has developed furthest in the center, Upper Carniola, where unstressed and short-stressed vowels $*_{i} *_{u}$ have become reduced to $\partial$ and were subsequently eliminated except in closed syllables, e.g., fan'tat $\int$ (standard fan'ti' $)$ 'little boy', 'kroh (standard k'ruh) 'bread', na 'krú:h (standard na k'rü $h u$ ) 'on the bread' (see also examples and discussion in footnote 4). Golush views this development as a consequence of the elimination of unstressed quantity relationships, and, further, claims

12 The Prekmurje dialect has eliminated pitch distinctions. See details on the developments in GreENBERG 1993. 
that short-stressed syllables are tantamount to unstressed because they are assigned by default to the word-final syllable in absence of a long (i.e., stressed) syllable (1977: 118-119). It is interesting to note in connection with Golush's analysis that in a peripheral dialect such as Prekmurje (Map 2: area 16), where quantity contrasts may occur in any stressed syllable, regardless of the position in the word, vowel reduction - which is manifested as the loss of labialization (where applicable) and slight centralization of high vowels - occurs only in unstressed position, e.g., Cankova f'tit' 'bird', 'it' 'to go', $n o k$ 'ryh 'on (the) bread'.

In addition to the parameter of stress, SRebot-Rejec as well as Petek, Śuštaršıc \& Komar have observed for Standard Slovene speech that vowel duration is markedly shorter in high than low vowels, i.e., "long" stressed $i$ is shorter than "long" stressed a (SREBot-Rejec 1988: 19-35). Similarly this hierarchy holds in "short" stressed and unstressed vowels, leading Petex, Sustararšıč \& Komar to conclude that "the traditional subdivision of stressed vowels into long and short ... appears to be questionable with regard to all the vowels that are divided into long and short, with the exception of /a/" (1996:4). See also the comments in footnote 5 of the present paper.

\section{A case of unchecked drift}

StanoniK 1977 reports a number of interesting developments in the word-prosodic system of the dialect of Žiri in the Poljane Valley (Map 2, area 41). In this dialect, long rising stress has become long falling, e.g., ab'lè:'ft 'to dress' (cf. Standard Slovene $b^{\prime}\left(e^{\prime}: f_{s i}\right)$. Long falling stress, in turn, has ceded prominence to the preceding syllable, which is realized as short rising, and the heretofore stressed syllable retains its length and falling intonation, e.g., 'kákò:J 'hen' (cf. Standard Slovene ko'kò:Л. Furthermore, the falling pitch in the unstressed syllable may contrast with a rising syllable that emerged in a similar fashion to that found in Smartno v Brdih (see section 6, paragraph 1, above), namely, stressed syllables preceding final elided vowels become rising, e.g., 'kákó:f 'hen (GEN. SG)', (cf. Standard Slovene $k \sigma^{\prime} k \dot{o}: f^{13}{ }^{13}$ ).

The developments in the Žiri dialect are at first glance aberrant with respect to Slovene, though not unlike cases elsewhere in which the values of the pitch oppositions have "switched", such as in Lithuanian and Bilo-Gora Kajkavian. Nevertheless, the explanations for the developments in Žiri are straightforward and in accord with some general trends already in place in Slovene dialects: in original rising stressed words, the high tone moved one mora towards the syllable onset; at the same time, original falling tone stress became reanalyzed as rising stress in the preceding syllable as a means of avoiding merger with the "new" falling stress. Though the effects are somewhat broader, the leftward movement of prosodic features away from word-final position is not unlike the retraction phenomena described in section 5 , above. The new rising pitch in final syllables arose later, along with the final phase of vowel reduction, which may be as recent a development as the $20^{\text {th }}$-century (see section 7 , paragraph 3 , above).

13 The change did not affect the previously adduced form akin to Standard Slovene $s b^{\prime} l e ́: ' f s i$, as it can be demonstrated that the final $-i$ in the infinitive was lost several centuries earlier than final high vowels in other categories. The standard form contains the final vowel on the basis of nineteenthcentury supradialectal reconstruction; in this case, the final vowel in the infinitive is attested in the northern peripheries of Slovene. 


\section{Contact phenomena and typological parallels}

As has been seen, Slovene (and the Kajkavian Croatian dialect) form a range of subtypes that set it apart from other pitch-accent languages in Europe. Notably, Slovene differs from most of Serbo-Croatian and the Baltic languages in having eliminated quantity distinctions apart from stress. Further, there is a dynamic tendency to rephonologize quantity contrasts as vowel-quality contrasts. This tendency is independent of pitch, which may be either retained or lost regardless of the quantity or quality relationships that hold in a given system. In general, pitch is lost most readily in certain contact situations, namely where Romance (Friulian, Italian) and Hungarian dialects have been in contact with Slovene. In particular, those in contact with Romance have tended, though not exclusively, to move towards stress-only systems. Those bordering with Hungarian have developed into stress and quantity systems, where quantity contrasts are limited to the accented syllable. On the other hand, Bavarian German dialects, which were historically in contact with the Upper Carniolan (Map 2, area I), and continue to be in contact with Carinthian (area V) dialects, have not affected the retention of pitch contrasts in the majority of these Slovene localities (see Table 5 for a summary of word-prosodic features in Slovene dialects). In all cases, however, the same structurally-driven changes affect virtually the whole of the Slovene dialect area. Thus, for example, all Slovene dialects have eliminated unstressed vowel quantity, except for aberrant varieties that have developed such (marginal) contrasts anew, as described in section 6, paragraph 1, above. The eastern Slovene dialects that have historically had contact with Hungarian agree in type with Hungarian only to the extent that they have resisted the innovation of lengthening non-final short stress; however, there is no tendency noted by which place of stress has become fixed or that unstressed quantity has developed or been preserved. Although it may be that pitch contrasts were lost as a result of contact, it is also evident that the preservation of more pervasive quantity contrasts as well as vowel quality contrasts would have made pitch contrasts carry a high degree of redundancy. In effect, any approximation of Hungarian word prosody is a result primarily of the persistence of archaism and not of contactmotivated innovation.

Slovene dialects share with Serbo-Croatian a tendency towards the elimination of final stress, but do not go as far as the most innovative (Stokavian) dialects of Serbo-Croatian in moving all stress, where possible, one syllable leftward (cf. Ivić 1958: 105ff.). Apparently, this is because in Slovene the innovations fit into a strategy of eliminating unstressed quantity, while in Serbo-Croatian the leftward movements of stress are independent of quantity contrasts (which have been largely preserved). Furthermore, the Slovene retractions tend to result in an increase in stressed-vowel quality contrasts, which, again, is not the case in Serbo-Croatian.

\section{Conclusion}

Slovene word-prosodic systems may be grouped into four types, depending on the phonemic contrasts that the systems employ: (1) stress, pitch, quantity; (2) stress, quantity; (3) stress, pitch; (4) stress. In each type, stress placement is ranked above pitch and vowel quantity, which depend on the place of stress. Throughout the Slovene dialect territory, a tendency toward rephonologization of vowel quantity as vowel quality contrasts has resulted in the type (4), where stress placement alone is the distinctive word-prosody feature. 
It is intriguing that most of the dialects that are conservative with respect to the preservation of prosody features are found not in the periphery but in the center of the territory. This can be explained by the fact that contact-induced change has affected the prosodic systems in the peripheries, though contact with German dialects has not had such an effect.

\begin{tabular}{|c|c|c|c|c|}
\hline Dialect & $\begin{array}{l}\text { Pitch contrast } \\
\text { in stressed } \\
\text { syllable }\end{array}$ & $\begin{array}{l}\text { Quantity } \\
\text { contrast in } \\
\text { any stressed } \\
\text { syllable }\end{array}$ & $\begin{array}{l}\text { Quantity } \\
\text { contrast in } \\
\text { word-final } \\
\text { syllable }\end{array}$ & $\begin{array}{l}\text { Unstressed } \\
\text { quantity }\end{array}$ \\
\hline \multicolumn{5}{|l|}{ I. Upper Carniola } \\
\hline 1 Upper Carniolan proper & + & - & + & - \\
\hline 2 Selca & + & - & + & - \\
\hline 3 Eastern Upper Carniola & - & - & + & - \\
\hline \multicolumn{5}{|l|}{ II. Lower Camiola } \\
\hline 4 Lower Carniolan proper & + & - & + & - \\
\hline 5 Eastern Lower Carniola & - & - & + & - \\
\hline \multicolumn{5}{|l|}{ III. Styria } \\
\hline 6 Central Savinja & - & - & - & - \\
\hline 7 Upper Savinja & - & - & + & - \\
\hline 8 Solčava & - & - & + & - \\
\hline 9 Central Styrian & - & - & - & - \\
\hline 10 S Pohorje & - & - & + & - \\
\hline 11 Kozjak & - & + & + & - \\
\hline 12 Kozjansko-Bizeljsko & - & + & + & - \\
\hline 13 Zagorje-Trbovlje & - & - & + & - \\
\hline 14 Lasko & - & - & + & - \\
\hline 15 Sevnica-Krško & - & - & + & - \\
\hline \multicolumn{5}{|l|}{ IV. Pannonian } \\
\hline 16 Prekmurje & - & + & - & - \\
\hline 17 Slovenske gorice & - & + & - & - \\
\hline 18 Prlekija & - & + & - & - \\
\hline 19 Haloze & - & + & - & - \\
\hline \multicolumn{5}{|l|}{ V. Carinthia } \\
\hline 20 N Pohorje-Remšnik & - & + & + & - \\
\hline 21 Mežica & \pm & - & - & - \\
\hline 22 Podjuna & + & $t^{*}$ & - & - \\
\hline 23 Obirsko & + & - & + & - \\
\hline 24 Roz & + & $+^{*}$ & + & - \\
\hline 25 Zilja & + & - & + & - \\
\hline 26 Kranjska gora & + & - & + & - \\
\hline
\end{tabular}




\begin{tabular}{|c|c|c|c|c|}
\hline Dialect & $\begin{array}{l}\text { Pitch contrast } \\
\text { in stressed } \\
\text { syllable }\end{array}$ & $\begin{array}{l}\text { Quantity } \\
\text { contrast in } \\
\text { any stressed } \\
\text { syllable }\end{array}$ & $\begin{array}{l}\text { Quantity } \\
\text { contrast in } \\
\text { word-final } \\
\text { syllable }\end{array}$ & $\begin{array}{l}\text { Unstressed } \\
\text { quantity }\end{array}$ \\
\hline \multicolumn{5}{|l|}{ VI. Littoral } \\
\hline 27 Rezija & - & - & - & - \\
\hline 28 Soča & - & & & - \\
\hline $29 \mathrm{Ter}$ & + & - & + & - \\
\hline 30 Nadiža & + & - & + & - \\
\hline 31 Brda & + & - & - & - \\
\hline $32 \mathrm{Kras}$ & - & - & - & - \\
\hline 33 Banšice & - & - & - & - \\
\hline 34 Rižana & - & - & - & - \\
\hline 35 Śavrini & - & - & - & - \\
\hline 36 Inner Carniola & - & - & + & - \\
\hline 37 Čicarija & - & - & - & - \\
\hline \multicolumn{5}{|l|}{ VII. Rovte } \\
\hline 38 Tolmin & - & + & + & - \\
\hline 39 Bača & - & + & + & - \\
\hline 40 Cerkno & - & + & + & - \\
\hline 41 Poljane & + & + & - & + \\
\hline 42 Skofja Loka & - & - & - & - \\
\hline 43 Črni vrh & - & - & + & - \\
\hline 44 Horjul & + & + & + & - \\
\hline \multicolumn{5}{|l|}{ Heterogeneous } \\
\hline 45 N Bela krajina & - & - & - & - \\
\hline 46 S Bela krajina & - & + & - & - \\
\hline 47 Kostel & - & + & - & + \\
\hline 48 Koðevje & n.a. & n.a. & n.a. & n.a. \\
\hline
\end{tabular}

\section{Table 5}

* Occurs, but with restrictions.

$\begin{array}{llll}\text { Abbreviations } & & & \\ \text { a } & \begin{array}{l}\text { long rising tone } \\ \text { short rising tone } \\ \text { long falling tone } \\ \text { a }\end{array} & \text { LH } & \begin{array}{l}\text { low-high (acute) } \\ \text { north }\end{array} \\ \text { a } & \text { accusative } & \text { N } & \text { northeast } \\ \text { a } & \text { central } & \text { NE } & \text { nominative } \\ \text { ACC } & \text { feminine } & \text { NOM } & \text { northwest } \\ \text { C } & \text { genitive } & \text { NW } & \text { plural } \\ \text { FEM } & \text { high-low (circumflex) } & \text { PL } & \text { south } \\ \text { GEN } & \text { instrumental } & \text { SE } & \text { southeast } \\ \text { HL } & & \text { SG } & \text { singular } \\ \text { INSTR } & & \text { St.SI. } & \text { Standard Slovene }\end{array}$




\section{References}

Bethin, Christina Y. (1998): Slavic prosody. Language change and phonological theory (Cambridge Studies in Linguistics 86). Cambridge: Cambridge University Press.

Fox. ANthony (1999): Prosodic features and prosodic structure. The phonology of suprasegmentals. Oxford: Oxford University Press.

Golush, Ruth A. (1977): The origin of vowel reduction in Slovene, in: Lencek, Rado (ed.), Papers in Slovene Studies, 1976. New York: Society for Slovene Studies, 107-119.

Grafenauer, Ivan (1905): Zum Accente in Gailthalerdialekte, in: Archiv fir slavische Philologie 27, 195-230.

Greenderg, Marc L. (1987): Prozodiexne možnosti v slovenskem knjižnem jeziku in slovenskih narežjih. Slavisticna revija 35, 171-186; [English translation:] (1992): The prosodic possibilities of Modern Standard Slovene and Slovene dialects, in: California Slavic Studies 14. 287-309. Berkeley, Los Angeles: University of California Press.

Greenberg, Marc L. (1992): Circumflex advancement in Prekmurje and beyond, in: Slovene Studies $14 / 1,69-91$.

GreenBerG, MARC L. (1993): Glasoslovni opis treh prekmurskih govorov in komentar k zgodovinskemu glasoslovju in oblikoglasju prekmurskega narecja, in: Slavistična revija 41/4, 465-487.

GreenBerg, MARC L. (2000): A historical phonology of the Slovene language (Historical phonology of the Slavic languages 13, ed. WEXLER, PAUL). Heidelberg: Universitătsverlag Carl Winter.

Gvozdanovic, JADranKa (1999): South Slavic, in: VAN DER HuLST, JerRY (ed.), Word prosodic systems in the languages of Europe. Berlin, New York: Mouton de Gruyter, 839-852.

Hombert, Jean-Marie (1978): Consonant types, vowel quality, and tone, in: Fromkin, Victoria (ed.), Tone: A linguistic survey. New York, London: Academic Press, 77-111.

Ivic, Pavle (1958): Die serbokroatischen Dialekte: lhre Struktur und Entwicklung (1. Allgemeines und die stokavische Dialektgruppe). The Hague: Mouton.

Ivıc, PAVLE (1982): O nekim fenomenima akcenatske varijacije koji nisu uvršteni u Ivšið̌ev koordinatnj sistem, in: Hrratski dijalektološki zbornik 6, 181-188.

Logar, TINe (1981 a): Šmartno v Brdih (OLA 4), in: Ivić, Pavle (ed.), Fonološki opisi srpskohrvalskih/ hrvatskosrpskil, slovenackih i makedonskih govora obuhvacenih opsteslovenskim lingvistickim atlasom. Sarajevo: Akademija nauka i umjetnosti Bosne i Hercegovine, 53-58.

Logar, Tine (1981 b): Potoze (Potschach; OLA 146), in: Ivic, Pavle (ed.), Fonološki opisi srpskohrvatskih/hrvatskosrpskih, slovenackih i makedonskih govora obuhvacenih opšteslovenskim lingvistickim atlasom. Sarajevo: Akademija nauka i umjetnosti Bosne i Hercegovine, 183-191.

Logar, Tine (1981 c): Kneža (Grafenbach; OLA 148), in: Ivic, PAvLe (ed.), Fonoloski opisi srpskohrvatskih/hrvatskosrpskih, slovenackih i makedonskih govora obuhvacenih opsteslovenskim lingvistickim atlasom. Sarajevo: Akademija nauka i umjetnosti Bosne i Hercegovine, 201-211.

LundBirg, Grant H. (2001 a): Typology of tone loss in Haloze, Slovenia: An acoustic and autosegmental analysis, in: Slovenski jezik/Slovene Linguistic Studies 3, 169-89.

Lunderrg, Grant H. (2001 b): Loss of tonemic oppositions in Eastern Haloze, Slovenia: An instrumental study, in: Balkanistica 14, 83-99.

Newexlowsky, GerHARD (1973): Slowenische Akzentshudien (Österreichische Akademie der Wissenschaften, Schriften der Balkankommission, Linguistische Abteilung XXI). Vienna: Verlag der Österreichischen Akademie der Wissenschaften.

Petek, Bojan, Sustarśsic, Rastislav \& Komar, Smiluana (1996): An acoustic analysis of contemporaty vowels of the Standard Slovenian language. (http:/www.asel.udel.edu/icslp/cdrom/voll/820/a820. pdf).

RJGLER, JaKoB (1963): Pregled osnovnih razvojnih etap v slovenskem vokalizmu, in: Slavisticna revija $14 / 1-4,25-78$.

RIGLER, JAKOB (1980): Nekaj opažanj pri akutu na zadnjem zlogu v slovenక̌cini, in: Slavistična revija 28/2, 291-222.

RIGleR, JAKOB \& Logar, TINe (1983): Karta slovenskih narecij. Ljubljana: Geodetski zavod SRS and Dopisna delavska univerza Univerzum.

Srebot-Rejec, Tatjana (1988): Word accent and vowel duration in Standard Slovene. An acoustic and linguistic investigation. (Slavistische Beiträge 226). Munich: Verlag Otto Sagner.

Srebot-Rejec, Tatjana (1997): Nekaj o stavěni intonaciji v knjižni slovenక̌ini, in: Slavistična revija $45 / 3-4,429-455$. 
Srebot-Rejec, Tatjana (1999): O tonemskem naglasu v nevtralnem stavčnem položaju v knjižni slovenšini, In JaN, Zoltan (ed.), Slovensko jezikoslovje danes in jutri (Zbornik Slavističnega društva Slovenije 10) Celje: Zavod Republike Slovenije za Solstvo, 125-132.

Stanonik, MariJa (1977): Govor Žjrovske kotline in njenega obrobja, in: Slavistična revija 25/2-3, 293-309.

TOPORISıC, JožE (1967): Pojmovanje tonemixnosti slovenskega jezika, in: Slavistična revija 15/1-2, 64-108.

TOPORıŠıČ, JožE (1968): Liki slovenskih tonemov, in: Slavisticna revija 16, 315-393.

ToPORıŠıC, JožE (1988): Tvorbeni model slovenskega knjižnega jezika, in: Slavistična revija 36, 133-180.

TOPORıŠIC, JoŽE (2000): Slovenska slovnica. Maribor: Založba Obzorja.

\section{Marc L. Greenberg}

Department of Slavic Languages and Literatures

University of Kansas

1445 Jayhawk Blvd., Room 2134

Lawrence, KS 66045-7590

USA

mlg@ku.edu 